present status and future outlook of forests comprehensively, with stacks of ecological and economic statistics and broad-scope analyses. Yet it could have been more adventurous. It largely supposes that forests' outputs will remain an extension of the past. What if China's construction boom were to cause its per-capita consumption of two main timber products, sawn wood and panels, to triple and match Indonesia's (not a high level)? China would become the world's leading importer of wood - and impose pressures on foreign forests far outstripping Japan's over the past several decades.

What, too, if certain wood applications were to be partially overtaken by substitutes for, say, paper pulp, as is already the case for 90 per cent of China's feedstocks, where rice straw and sugar-cane bagasse have been substituted for pulp feedstocks? What if many uses of construction timber were to give way to substitutes such as alloys and composites, as is already the case in many developing countries, where people use mud bricks reinforced with chopped sisal or elephant grass? According to a report by the UN Centre for Human Settlements (An Urbanizing World: Global Report on Human Settlements, 1996, Nairobi, Kenya), within the next decade, developing countries will need to build at least 250 million new dwellings, or half as many as have been built since we came out of our caves. What if biotechnology were to enable us to grow square trees (along the lines of the square tomatoes we already have), providing twice as much board timber as round trees?

Norman Myers is at Upper Meadow, Old Road, Oxford OX3 8SZ, UK.

\section{Experimenting with drugs}

\section{Instant Pharmacology}

by Kourosh Saeb-Parsy, Ravi G Assomull, Fakhar Z. Khan, Kasra Saeb-Parsy and Eamonn Kelly

Wiley: 1999. 349 pp. \$34.95, £19.99 (pbk)

\section{John Foreman}

Writers of undergraduate medical textbooks have a knowledge and enthusiasm for their subject that often results in a massive book, intimidating students with its size, depth and breadth. Instant Pharmacology is a novel departure from this because its

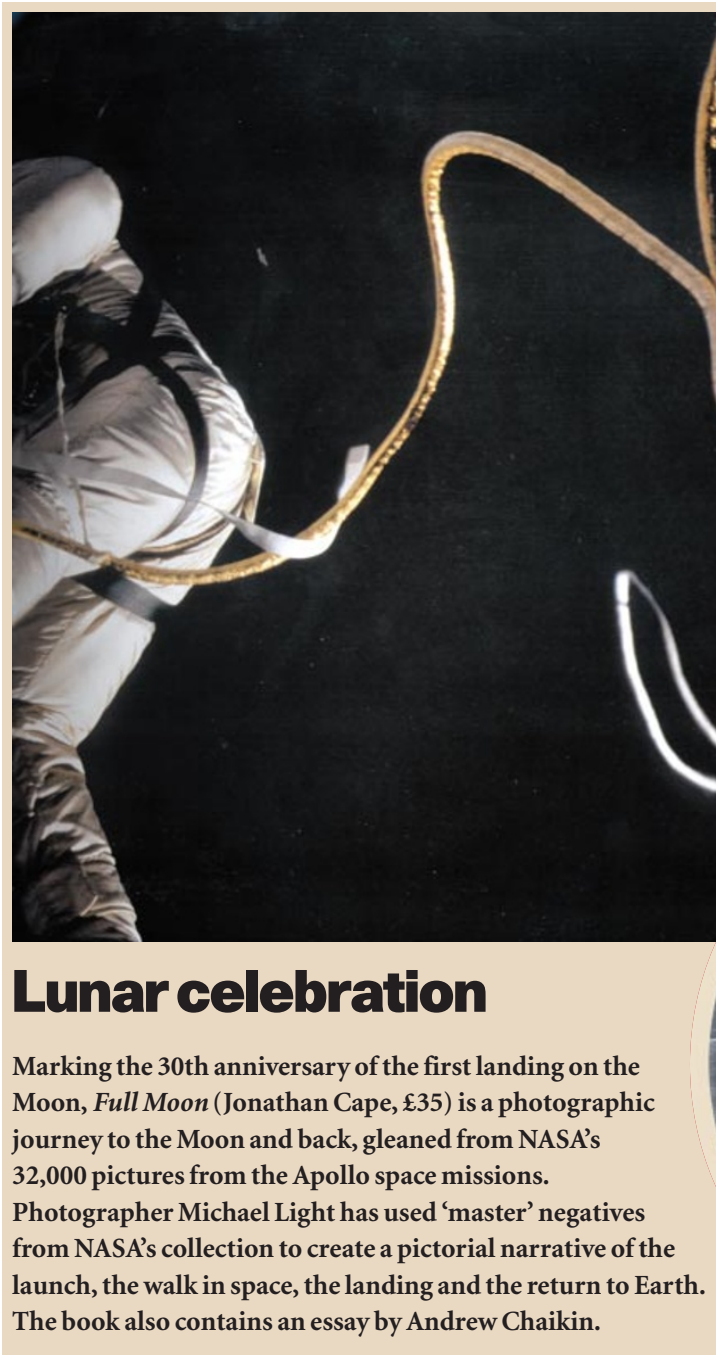

The book also contains an essay by Andrew Chaikin. writers are students themselves.

The book also departs from the standard format of pharmacology texts. The first section, which describes the basic principles of drug action, is followed by sections on the principles of chemical transmission and the mechanisms of drug action on the different body systems. Next comes a dictionary of drugs, set out in alphabetical order of generic drug name. The final section is a set of questions and answers designed to aid selfdirected learning.

The book is appealing because it is concise and shorter than many of the current major textbooks. The dictionary of drugs is a useful way of locating information on a particular drug. The format lends itself to the systems-based approach to medicine that many medical schools are now adopting, and the actions of drugs are successfully placed in the relevant clinical contexts. No doubt, students will like the idea that their peers have written the text with a view to removing all that is not core material.

Some problems, however, arise from the novel format and the content. The text contains features that are likely to mislead or confuse the student reader. For example, the peptide hormones angiotensin and bradykinin have been classified as neuropeptides, and the duration of warfarin's action is attributed to the rate of catabolism of clotting factors rather than to the half-life of the drug.

One of the problems that students new to pharmacology encounter is the sheer volume of drug names. An introductory text should concentrate on mechanisms of action and provide only main examples of each type or sub-type of mechanism. But Instant Pharmacology has numerous examples of each mechanism in some areas and few in others.

There are tensions between the main text and the dictionary. The main text is not very informative about the mechanisms of action of some drug classes, and the dictionary contains information that more logically would have been placed in the text, since it relates to the mechanism of action. In other cases, the text is merely repeated in the dictionary.

There is a place in the market for a concise introductory pharmacology text. It remains to be seen whether students will appreciate the novel approach in this book.

John Foreman is in the Department of Pharmacology, University College London, Gower Street, London WC1E 6BT, UK.

\section{Newinpaperback}

Forbidden Drugs, 2nd edn

by Philip Robson

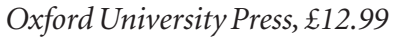

